\title{
BAMBATHA AT MPANZA: THE MAKING OF A REBEL
}

\section{P.S. Thompson}

Privately published, 2004

128 pages

Maps, abbreviations and short tittles used

Bibliographical essay

ISBN $\mathrm{Pb} \mathrm{0-620-31692-6}$

Bambatha is widely known as the chief who led a group of men to confront the Natal colonial government in protest against poll tax. He lived in a broken, sandy and stoney area known as Mpanza valley, to the north of Greytown, in the Natal colony of the former British Empire. The inhabitants of this valley were the Zulu tribe called Amazondi (officially called Abasengome). This land was dry and poor for cultivation and for game. It was a farmland owned by white men but settled by the Amazondi since 1854 as a "private location" of indigenous people who did not live in an officially designated Native Location (an exclusive site for the settlement of indigenous people). The white people were called the thorns. Bambatha led the last armed resistance of the Africans before the establishment of the Union of South Africa in 1910 . He was eventually captured and beheaded. He provided the source of strength to boost the morale of those who continued with the struggle for liberation in subsequent years. This is the perception around Bambatha and his rebellion in 1906. But how exactly did it happen that he became a defiant chief who did not acquiesce to the demands of the colonial government? This book provides a descriptive analysis of the career of Bambatha until his flight to Zululand after the failure of his endeavour-armed resistance.

The reader is immediately struck by the title: "The making of a rebel." This creates an impression that Bambatha was not inherently a rebel, but he was made to become one. The expectation is that this book will provide answers with respect to why he became rebellious. After going through nine chapters, which make up the entire book, one is inclined to agree that Bambatha was confronted with many problems that accounted for his conduct. Thompson describes a number of situations in which Bambatha found himself unhappy and he attributed that to the colonial 
authorities. He was expected, like all other chiefs after the Anglo-Zulu War of 1879 and the Zulu Civil War in 1880s, to subject himself to and comply with the colonial administrative and legislative requirements. The colonial authorities had the power to approve the appointment of chiefs or depose them if they did not fulfil their designated duties: as extensions of colonial rule in executing the mandate of maintaining law and order. It is against this background that Bambatha was found wanting by the authorities that he was eventually deposed.

Thomson precedes the first chapter with a brief description of the encounters between Bambatha's men and the colonial force. It becomes a standard practice throughout the book to devote a few pages to what he refers to as intermezzi. This is just a brief interval to give attention to other essential aspects that might impact on the normal coherence of the discussion. The first chapter begins with the socioeconomic conditions that impacted on the lives of the Zondi community and Bambatha's accession to power. Thompson describes the lineage in small details including his parentage and the regency of his uncle, Magwababa. Apparently, this uncle became the source of Bambatha's discomfort later because of the recognition (and the allowance which was terminated after Bambatha's complaint) given by the colonial authorities to his (Magwababa's) management of the Zondi tribe, after Bambatha's accession to chieftaincy, in 1890. The economic conditions of the Abasengome people (as used interchangeably in this book with the Amazondi) are described. These were some of the factors that accounted for the frustration of the people who were obliged to make payments they have had to make on rents, dogs, huts, etc. The people incurred debts due to difficulties in payments. Bambatha was one of those who appeared many times in court on debt charges. This strengthened his resolve to challenge the colonial authorities. Thompson continuously provides a description of interrelationships between sections of people living in the Natal colony, especially with regard to sources of conflict amongst them.

Chapter two commences with the analysis of the resident magistrate of the Umvoti Division, John Cross, where Bambatha and his people were located. This resident magistrate began with "very strong stuff": exalting whites, intimidating headmen, demanding respect and reminding the headmen that the government owned the land. Cross apparently decided to deal harshly with prevalent faction fighting. He felt so undermined when people fought in his division that he applied flogging as means to curb such fights. As a result he held Bambatha personally responsible for one of the faction fights that proved to be his (Bambatha) doing. Here, Thompson paints a picture of the circumstances of Bambatha's road to oblivion. Most importantly, the issue of the census in 1904 that was perceived by Abasengome as a means to determine the number of people living in the area for taxation purposes. Such a concern was raised by Bambatha given its future 
implications. This point of census reveals the challenge that Bambatha was posing to the authorities. Apart from this, Thompson clarifies the issue surrounding Bambatha's deposition from the chieftaincy. It resulted from the faction fight between the Abasengome and the Ntendeni in which Bambatha was involved. He was accused of active participation and deposed as a result.

In chapter 3, the real issue used as a reason for Bamabatha's activities by many historians emerges, the poll tax. Following the government's financial problems resulting from the after effects of the South African War, 1899-1902, the Poll Tax Act, no. 38, of 1905 was passed. It was expected of males from 18 years of age to pay an annual tax of one pound. Thompson clarifies the implications of this tax and how the Abasengome linked it to the census of 1904. Following this, he then separates chapter 3 and 4 with an intermezzo where he gives attention to the description of Greytown and its significance to the area around which Bambatha lived.

According to the colonial authorities, Bambatha was supposed to report anything relating to fighting or armed resistance. He did not, so he lost credibility in the eyes the government and it was decided that he should be deposed. These developments are captured in chapter 4 . It is for the first time that the name of the governor, Sir Henry MacCallum, is mentioned in this book. This is in view of the role he played in the dismissal of Bambatha. He signed letter to the effect that Bambatha was to be relieved of his duty in favour of Magwababa. The details of the instructions to various stakeholders are well elaborated. Bambatha 's defiance of the government order and his preparation to take revenge on those who testified against him during the trial relating to the faction fight is carefully developed in this chapter. The fear of death is cited as a reason for Bambatha to refuse to go to Pietermaritzburg to see the Minister for Native Affairs. The name of the minister is not mentioned. Another development is the acceptance by Magwababa of his appointment as chief. This further accounts for Bambatha`s anger at Magwababa for accepting the chieftaincy and he became the focus of his initial activities. Bambatha was then left with 3 options: confront the enemy, surrender, or flee.

Thompson brilliantly explains the frustrations of Bambatha and his ultimate decision to flee to Zululand, where Dinuzulu, "chief" of the Zulu (new title as a result of the division of Zululand into numerous chiefdoms after the Anglo-Zulu War) was based. This is contained in chapter 5. The whole itinerary of Bambatha and his daily encounters at different kraals is well described in this chapter. The main feature of this chapter is the juxtaposition of the conversation between Bambatha and Dinuzulu because of insufficient information regarding its actual content. The reader is given an opportunity to reflect on both accounts from the 
royal family and from Bambatha 's family. Thompson recognises the irreconcilable nature of the statements made by the two parties with regard to what happened during Bambatha's visit to Zululand. Because of the difficulty in ascertaining the objective truth, it is the best option by Thompson to place the statements before the reader for judgement. There are about eleven pages devoted to the juxtaposed royal and family versions in the book. This is just an indication of the inadequacy of the sources that were available to the author. The reconstruction of Bambatha's itinerary from Usuthu (Zululand) back to Natal is based on the accounts of Ngqengqengqe and Sukamekuluma, the two emissaries for the king.

Chapter 6, constitutes the return of Bambatha to Mpanza to raise the rebellion. It is about the establishment of the fact that depositions or evidence given in court (with regard to Dinuzulu's suspected complicity in the rebellion) at the time were mainly self-serving to avoid conviction. Their reliability including those juxtaposed in chapter 5 is in question. Apparently, there is still no source that can provide the actual version of events prior the outbreak of the rebellion. The question that needs to be answered is how did Bambatha get hold of three firearms (mauser, carbine, double-barrel muzzle loader) instead of only one, which he had when he left for Zululand?

A new development emerges in chapter 7: recapitulation. The author summarises the main points about chapter 6 to establish a link as events unfolded. This is about Bambatha's return to gather an armed following and confront the colonial government. The author paints a picture of the preparation of Bambatha's men in their traditional attire for war. What is of interest in this chapter is the trial of Magwababa. He is subsequently found not guilty to the charges by Bambatha, but falls victim of coercion to participate in the rebellion. Another significant issue is the attention given to prayer conducted by Moses at several junctures when there is a gathering. The purpose of the prayer is to provide strength to defeat the enemy. The reader is left with the impression that Christianity had already taken root within the African communities at that time. Nevertheless, there is a description of rebellious acts by the impi, and the acquisition of more weapons (eight firearms). The chapter ends with a summary of what happened in Mpanza, referred to as "the rebellion" by popular literature.

On 4 April 1906, Bambatha continues with the planned course of action from his operational base at Mqombani`s kraal. These military developments are discussed in chapter 8 . All the tactical plans i.e. scouting, deployments, and ambush are put into operation. Thompson pauses here and changes to focus on the colonial government. Attention is given to the organisation of defence, the strength of the force (various units) and the supplies. Thompson spents some time on military 
events (terrain, strength of opposing forces, order of march and deployments) regarding the battle between Bambatha and Cross's force. The battle opens with the surprise attack on the van of the Natal Police, melee, and the reaction of the main body, which was far back. Casualties favoured the rebels since non of them died, only four wounded as opposed to three killed, four wounded on the Natal Police's side.

In chapter 9, a summary of the main events from chapter 8 is provided. A postmoterm of the battle is held. On Bambatha`s side, the force regrouped to assess the rate of success after their encounter with the colonial police. There are normal post-war rituals performed and the celebrations and determination of the spoils of war. The colonial authorities were "galvanised in action." They mobilised a large force and powerful weaponry (artillery) in order to "sweep" Mpanza clean of any rebels. Bambatha was in an untenable situation with no allies, limited strength and lack of material support. As a result, he had to flee to Zululand. Following Bambatha's departure, on 6 April 1906, the colonial field force commenced with their Mpanza operations. The retributive acts by the colonial force included collection of livestock, imprisonment and burning of kraals belonging to rebels and suspects. Nothing with regard to Bambatha's departure and what happened to him after his flight is revealed in the book.

An asset of this book is the impressive array of primary sources, especially archival records. Thompson also gives recognition to available literature on Bambatha. He refers to only two books: James Stuart, London: Macmillan, 1913 and Shula Marks, Oxford, Claredon Press, 1970, as devoting attention to the background of Bambatha. Most sources pays scant attention to this part of history, and Thompson's contribution fills a niche in explaining why Bambatha became a rebel.

Another quality of the book is his acknowledgement of its limitations in the foreword. He indicates the purpose for writing the book: "It is not an indictment or glorification of Bambatha. It is an elucidation of the antecedents of his rebellion and his role in it." It is upon the reader to reflect on these aspects of development towards the outbreak of the rebellion. The book is not an exhaustive account of the Bambatha rebellion, but an explanation of causality to armed action against the colonial government. It might prove tedious to the reader to constantly refer to maps placed at the end of the book. It breaks the rhythm of reading by pausing, paging all the way to the end, then returning to the text. It would have been better for the maps to be placed within the text as part of the discussion to keep the reader focused.

In the final analysis, the value of this book lies in the depth of the research. It has extensively covered most of the daily events in their context and the activities of specific role players. However, it leaves the reader a bit mind boggled with all the 
names thrown in at every turn. The reader is still left with the feeling that the book is incomplete because one would like to know what eventually happened to Bambatha. As a reading and reference material, the books offers a good account of significant events. It is an important contribution to the development of arguments for the outbreak of the rebellion in 1906, especially the critique of the introduction of the poll tax.

Fankie Monama, Subject Group Military History, Faculty of Military Science, Stellenbosch University 